\title{
IPO VALUATION AND IPO INTER-INDUSTRY EFFECTS
}

\author{
İlk Halka Arzlarda Değerleme ve İlk Halka Arzların Sektörel Etkileri
}

\section{S. Burcu AVCI*}

\begin{abstract}
Keywords:

IPOs, Valuation, Underpricing, Intra-Industry Effects, Price-to-Value Ratios.

JEL Codes:

G11, G23, G32

This study examines the valuation effects of initial public offerings (IPOs) and intra-industry effects of IPOs in Turkey between 2010 and 2018. The purpose of this study is to find out whether initial public offerings are overvalued and whether they impact the pricing of industry peers. First, the valuation of IPOs is investigated. Price-to-value ratios of Turkish IPOs are compared with sector average ratios to determine whether IPOs are overvalued. Turkish IPOs are not overvalued against industry rivals' price-to-value ratios based on sales and earnings-before-interest-taxes-depreciation-and-amortization (EBITDA) and earnings. Similarly, valuation based on price-to-value ratios is not related to initial pricing of IPOs. Second, the intra-industry effects of IPOs are investigated. Sector-adjusted abnormal returns of IPOs are compared to marketadjusted abnormal returns. The results are not affirmative: There is no statistically significant difference between the two abnormal returns. Turkish IPOs do trigger significant price declines on rival companies' stocks. Altogether, the findings indicate that there is neither overvaluation of IPOs nor intraindustry effects over rival companies. Companies do not time the market based on industrial overvaluation. This may indicate market efficiency or lack of competition in the IPO market.
\end{abstract}

Anahtar Kelimeler:

İlk Halka Arz,

Değerleme,

Düşük Fiyatlama,

Sektörel Etkiler, Fiyat-Değer Oranları.

JEL Kodları:

G11, G23, G32
$\ddot{\mathbf{O} z}$

Bu çalışma 2010 ve 2018 döneminde Türkiye'deki ilk halka arzların değerleme etkileri ve sektörel etkilerini incelemektedir. Çalışmanın amacı ilk halka arzlarda yüksek değerlendirmenin ve ilk halka arzların aynı sektörde faaliyet gösteren halka açık şirketlere olumsuz bir fiyat etkisinin tespit edilmesidir. İlk halka arzların göreceli değerlerini belirlemek için fiyat-değer oranları, sektördeki diğer firmaların ortalama fiyat-değer oranları ile karşılaştırılmaktadır. Fiyat-değer oranları satışlar; faiz, amortisman ve vergi öncesi kar (FAVÖK); ve net kazanç tutarları kullanılarak hesaplandığında ilk halka arzlar yüksek değerlendirilmediği görülmektedir. Fiyat-değer oranları ilk halka arzların fiyatlaması ile de anlamlı bir ilişki sergilememektedir. İkinci olarak, ilk halka arzların sektörel etkilerini incelemek için ortalama pazar getirisine göre ayarlanmış anormal getiriler, ortalama sektör getirisine göre ayarlanmış anormal getirilerle karşılaştırılmaktadır. Sonuçlar olumlu değildir: Her iki getiri arasında istatistiksel olarak anlamlı bir fark bulunmamaktadır. Bu da ilk halka arzların rakip firma fiyatlarında bir düşüşe neden olmadığını göstermektedir. Sonuçlar beraber ele alındığında halka arz edilen hisse senetlerinde yüksek değerlendirme görülmemekte, ayrıca ilk halka arzlar sektördeki rakiplerin fiyatlarında etki yapmamaktadır. Şirketler halka arz edilmeyi planlarken sektörel bazda pazar zamanlaması yapmamaktadırlar. Bunun nedeni pazarın etkinliği olabileceği gibi ilk halka arz pazarındaki zayıf rekabet de olabilir.

\footnotetext{
* Dr., Visiting Researcher, Sabanc1 University, School of Business, Department of Finance, burcu.avci@sabanciuniv.edu, ORCID: 0000-0001-8056-850
}

Makale Geliş Tarihi (Received Date): 25.11.2020 ～Makale Kabul Tarihi (Accepted Date): 19.07.2021 


\section{Introduction}

Given the diversity of performance of firms across various industries, understanding and controlling for industry-level variation is an important tool for corporate finance studies. Industry membership is a fundamental determinant of firms' stock price performance, growth, cost of capital, and many other financial ratios (Fairfield, Ramnath and Yohn, 2009; Gebhardt, Lee and Swaminathan, 2001; King, 1966; Lev, 1969; Ohlson and Juettner-Nauroth, 2005; Schmalensee, 1985). Systematic inter-industry differences provide diverse opportunities and threats to companies. These opportunities and threats can be a determinant of price formation in initial public offerings. Companies may take advantage of the markets during an industry upswing and go public while valuation of the firms in a specific industry is high (Baker and Wurgler, 2002; Pagano, Panetta and Zingales, 1998).

On the other hand, membership of an industry may also negatively affect a publicly traded firm's price if rival companies decide to go public (Akhigbe, Borde and Whyte, 2003; Slovin, Sushka and Ferraro, 1995). There is evidence that prices of publicly traded companies decline around a rival's initial public offering. This can be an indicator of issuing company's overvaluation against industry rivals (Jain and Kini, 1994; Pagano et al., 1998). Going public may force increased competition and pull down the market prices of rival firms (Akhigbe et al., 2003).

Turkish initial-public-offering (IPO) underpricing is well documented, whereas industrial valuation effects and intra-industry effects of IPOs have not been fully investigated. This study aims to fill this gap by testing whether industry valuation effects have a significant relation with the decision to go public. To investigate these industry-level relations, we analyze the universe of 124 IPOs for nine years between January 2010 and December 2018 in the Turkish Stock Exchange.

The first stage of empirical analysis investigates the valuation effects of IPOs using price multiples in the Turkish IPO market. We compare price multiples and initial returns of the issuing company to those of industry averages or industry index values to find the abnormal values and abnormal returns. Earlier international research compares these ratios to a peer's ratios to determine whether an IPO is overvalued. This approach is neither feasible nor desirable for Turkey due to small number of possible peers. This study uses industry averages in order to retain a maximum number of IPOs in the sample.

Price-to-value (P/V) ratios based on sales, earnings, and earnings-before-interest-taxesdepreciation-and-amortization (EBITDA) ratios of IPO firms are compared with those of industry averages. The median values of comparative P/V ratios (IPO versus sector) are significantly less than one. In fact, IPO firms have higher sales than industry rivals; however, their EBITDA and earnings values are about industry averages. The regression analysis between $A R$ and $\mathrm{P} / \mathrm{V}$ ratios does not provide significant results, indicating that IPO valuation against industry rivals is not related to initial abnormal returns.

The second part of this analysis measures intra-industry effects of IPOs. An indirect method is chosen to measure the impact of IPOs over rival companies. Sector-adjusted abnormal initial returns and market-adjusted abnormal initial returns are analyzed to determine if rival companies in the same sector experience a negative impact due an IPO. If sectoradjusted abnormal returns are significantly higher than market-adjusted initial returns, than we 
can claim that industry peers are negatively impacted from the IPO. However, our findings are insignificant, indicating no significant price effects of IPOs over rival firms. Moreover, earlier research claims that the negative price effects of IPOs should be more intensive in hot issue periods. Once again, our analysis does not provide any support for this hypothesis either. These findings show that industry dynamics affect issuing companies' choices to go public whereas a company's decision to go public does not affect public peers' market values.

The findings in the first part of the analysis show that issuing firms are not overvalued relative to the industry rivals. The findings in the second part of the analysis show that issuing firms do not affect the prices of industry rivals, supporting the findings in the first part. Issuing firms are neither overvalued nor undervalued. Firms do not time the market when they consider for an IPO. These findings, together, can be an indicator of market efficiency or lack of competition in the market. Since strong market efficiency was rejected by earlier research (Duman Atan, Özdemir and Atan, 2009; Turan Kurtaran, Kurtaran and Kurtaran Çelik, 2018; Yücel, 2016), we believe lack of competition is a stronger cause.

This study has two important contributions to Turkish stock market literature. First, this is the first study that uses industry-benchmark approach to measure the valuation of IPO firms as well as valuation effects on rival firms. Valuation of IPOs has been neglected in the Turkish IPOs and existing studies are limited in number. The only study, to the best of our knowledge, is Tütüncü (2020) so far. Tütüncü (2020) however is different from this study since it focuses on underwriters' reports, and not industrial valuation of IPO firms or their rivals. Second, this study establishes that Turkish IPO market is not characterized by overvaluation. The underlying reasons for this lack of overvaluation requires further research in the future.

This remainder of the study is organized as follows: Section 2 reviews the theoretical and empirical literature on valuation of IPOs and intra-industry effects of IPOs. Section 3 comes up with hypotheses. Section 4 presents methodology and sample selection process. Section 5 presents empirical results. Section 6 concludes.

\section{Literature Review}

\subsection{Valuation of IPOs}

Managers use private information to decide when to issue shares. Their private information allows them to choose the optimal strategy of going public that would maximize shareholder wealth. They would prefer to issue shares when the company equity is overvalued. If equity is undervalued, managers would delay the issuance until the market overvalues the equity again (Lucas and McDonald, 1990). Having put forth the basic theory, we now focus on the specifics of how to value an issuing firm.

As valuation is a complex issue, several valuation techniques for the issuing firms have been developed so far. One method uses underwriters' ex-ante valuation. To assess whether a firm is mispriced, its aftermarket price is compared to the pre-issue value estimated by underwriters. Several studies using this method find that the IPOs are overvalued and part of the overvaluation is related to initial underpricing (Crosby, 2000; Deloof, De Maeseneire and Inghelbrecht, 2009; Paleari and Vismara, 2007; Parker, 1999; Roosenboom, 2012; Tütüncü, 2020). Another method uses analysts' forecasts (Chahine, 2004; Paleari and Vismara, 2007). 
These findings show that analysts are usually overoptimistic about IPOs and their forecasts lead to overvaluation of the intrinsic value of issuing firms.

The last method is the comparison of fundamental values of issuing companies with those of public peers (Colaco, De Cesari and Hegde, 2017; Kim and Ritter, 1999; Purnanandam and Swaminathan, 2004). Fundamental valuation ratios are compared to determine any mispricing of equity in this method. Current stock prices can be a measure: If stock prices are higher than past prices, usually at market peaks, then firms issue more stocks (Schultz, 2003). Another measure used in the literature is market values. If current market values are higher than past market values, companies should issue equity. Similarly, if market prices are higher than book values (for the companies whose book values are generally higher than market values), it can be an optimal time to issue stocks (Baker and Wurgler, 2002). Another measure is industry's market-to-book ratio. Firms rush to issue equity if industry's market-to-book ratios increase (Pagano et al., 1998). Price-to-earnings, market-to-book, and price-to-sales ratios have also been used to measure valuation (Kim and Ritter, 1999). A simple and straightforward valuation method is to use comparable valuation methodology, employing price-to-value $(\mathrm{P} / \mathrm{V})$ ratios (Geddes, 2003, p. 77). P/V ratios or fundamental variables used to compute P/V ratios are publicly available and it is easy to communicate these ratios (Sahoo and Rajib, 2013). In this type of analysis, IPO firms and their public peers are compared based on P/V ratios (Alford, 1992; Bhojraj and Lee, 2002; Cassia, Paleari and Vismara, 2004; Chang and Tang, 2007; Cotter, Goyen and Hegarty, 2005; Firth, Li and Wang, 2008; Kim and Ritter, 1999; LeClair, 1990; Lie and Lie, 2002; Sahoo and Rajib, 2013).

Among all, Purnanandam and Swaminathan (2004) match IPO firms with a peer from the same sector and similar size. Then, they compute price-to-value $(\mathrm{P} / \mathrm{V})$ ratios based on companies' sales, EBITDA, and earnings values. They find that companies issue equity when $\mathrm{P} / \mathrm{V}$ ratios of companies are significantly greater than peer companies' ratios. This finding implies that companies issue equity when the IPO companies' valuation based on sales, EBITDA, and earnings are higher than peers' valuations. These results partially support the market timing hypothesis.

Recent international evidence is provided for a limited number of countries. Firth et al. (2008) analyzes the value of Chinese IPOs by using their book-to-value ratios. They compare IPOs providing price-earnings $(\mathrm{P} / \mathrm{E})$ multiples in the book-building process with the ones that do not provide $\mathrm{P} / \mathrm{E}$ multiples. They find that disclosing $\mathrm{P} / \mathrm{E}$ multiples add value to explain price formation process. P/E multiples convey information about the quality of the issuing firms. Indian evidence shows that IPOs are not overvalued when they apply the peer's matching methodology suggested by (Purnanandam and Swaminathan, 2004). Then, this paper shows that there are some overvalued IPOs among all, and they continue analyses by separating undervalued and overvalued IPOs (Gupta and Suri, 2017). A similar methodology was used for Malaysian IPO market (Ong, Mohd-Rashid and Taufil-Mohd, 2021). Results show that price earnings, sales, book multiples explain an important variation in the pricing formation of IPOs.

No study measures valuation effects of Turkish IPOs to the best of our knowledge. The only study analyzing valuation effects in Turkish IPOs uses underwriters' reports. This study documents that underwriters use market multiples method most often. Underwriters prefer comparing issuing firm's multiples with those of peers in 82 percent of the cases; however, an important number of underwriters compare issuing firm's multiples with the multiples of an 
index, such as industry index or BIST index (Tütüncü, 2020). Comparing P/E multiples to an index is in line with the fact that a suitable peer does not exist in the domestic market because the number of publicly traded firms is small in emerging market stock exchanges (Firth et al., 2008; How, Lam and Yeo, 2007).

\subsection{Intra-Industry Effects of IPOs}

The effects of significant corporate activities on rival firms' stock price behavior have been analyzed in the literature. Examples are bankruptcy announcements (Cheng and McDonald, 1996), seasoned equity issues (Slovin, Sushka and Polonchek, 1992; Szewczyk, 1992), and bond rating downgrades (Akhigbe, Madura and Whyte, 1997). Similarly, literature provides empirical findings of intra-industry effects of IPOs. The pioneer studies in this research area focus on equity carve outs while later studies focus on straight equity issues.

Earlier studies in this area explain the intra-industry effects through information asymmetries. Managers decide to go public if they have an informational advantage over outside investors (Nanda, 1991; Welch, 1989). The informational advantage may provide pricing benefits to IPO firms either by their own overvaluation or rival firms' undervaluation. Nanda (1991) finds negative valuation effects on rival firms of carved-out subsidiaries. Carveouts are initial public offerings of subsidiaries. The results show that firms prefer issuing carveout stocks when subsidiaries are overvalued (and parent companies are undervalued). If parent company is overvalued, then firms prefer issuing equity in the parent company. Slovin et al. (1995) find similar results; the authors measure rival companies' price changes on the announcement date of equity carve-outs, spin-offs, and asset sale-offs. They find negative returns of rival companies of carve-outs on the announcement dates in contrast to positive returns of spin-offs and asset sales-off. Spin-off and asset sales-offs are not equity offerings; thus, opposite price reactions in carve-outs is due to equity offerings. They also measure the intra-industry effects of conventional IPOs and find similar negative results.

Later research provides strong evidence for negative stock price reactions of rival firms' successful IPOs, and positive stock price reactions of rival firms' withdrawals of IPOs. The negative stock price performance is significant in competitive sectors, high-performing industries, and high-risk industries. The effects are stronger if IPO firms use proceeds to reduce leverage (Akhigbe et al., 2003). Reduction in leverage provides competitive advantage over highly levered rivals (Chevalier, 1995; Phillips, 1995). Spiegel and Tookes (2020) shows that it is mostly industry-wide developments that would cause rivals' performance declines in the postIPO process, however, there are still some large IPOs that trigger rivals' performance to decline.

Another explanation of the competitive advantage can be overoptimistic IPO investors, especially in hot markets. The over-optimism may cause an underestimation of industry effects of rival firms. Rival firms can minimize the underestimation during a rival's IPO by repurchasing stocks (Nguyen, 2011). As a result, issuance gives the market a signal for the upcoming correction in market prices and unfavorable industry conditions (Jain and Kini, 1994; Pagano et al., 1998). 


\section{Hypothesis}

Market timing theory focuses more on information asymmetries and claims that companies go public not to enjoy growth opportunities, rather to enjoy valuation benefits. Companies go public to benefit from information asymmetries existing in the market; managers know the intrinsic value of the equity better than investors, and they choose to go public if the equity is overvalued (Lucas and McDonald, 1990).

The theory does not specify how to measure the mispricing. As a result, several studies developed different models to measure mispricing: Managers would issue equity if their equity is overpriced relative to historical prices (Baker and Wurgler, 2002; Schultz, 2003); book values (Baker and Wurgler, 2002); book-to-market ratios (Pagano et al., 1998); fundamental ratios such as price-to-earnings, market-to-book, and price-to-sales (Alford, 1992; Bhojraj and Lee, 2002; Chang and Tang, 2007; Cotter et al., 2005; Firth et al., 2008; Kim and Ritter, 1999; Sahoo and Rajib, 2013) or P/V ratios computed based on peer companies' fundamental values such as sales, EBITDA, and earnings (Gupta and Suri, 2017; How et al., 2007; Ong et al., 2021; Purnanandam and Swaminathan, 2004). The common outcome of all these studies is that companies prefer going public when their equity is overpriced. As a result, the first hypothesis tests if this phenomenon holds for Turkish IPOs.

\section{$H_{1}$ : Companies go public if they are overpriced compared to industry peers.}

Like other corporate events, IPOs provide signals to market participants about the prospects of the industry. For example, pioneer IPOs (the first IPO in a given industry) create positive externalities for industry peers, namely that the pioneer industry is performing well. Rival firms enjoy this positive externality from pioneer firms' information sharing with the market (Benveniste, Ljungqvist, Wilhelm, and $\mathrm{Yu}, 2003$ ). If there are growth opportunities for the industry, and some firms engage in IPOs to raise funds, then the investors will learn about it and invest in pioneers and followers (Akhigbe, Johnston and Madura, 2006). Potential investors learn about the qualities of the industry during the registration period of pioneers. As a result, more companies go public after pioneer IPOs register to issue equities (Lowry and Schwert, 2002). Therefore, an IPO can reveal positive information about the industry and stock prices of rival firms can increase on the IPO date.

On the other hand, many other studies suggest that IPOs can also provide negative externalities on rival companies. Investment banks can use rival company multiples to evaluate IPOs, therefore, rival companies will perform similar to IPO firms (Kim and Ritter, 1999). If firms time the market to go public, it is expected that the IPO firm is overvalued. Because industry returns are cross correlated, going public would reveal a negative signal about rival firms' valuation. Rival firms are likely to be overvalued by the time of IPOs (Jain and Kini, 1994; Pagano et al., 1998). There is evidence that IPO firms' operational performance fall in the aftermarket period, either because of market timing or because of exaggerated earnings just before IPOs (Teoh, Welch and Wong, 1998). Moreover, new issues can be a signal of lack of trust to managers (Ross, 1977). Additionally, IPO firms can be a threat to industry rivals to force increased competition or pull market share away from rivals (Akhigbe et al., 2003). The second hypothesis tests if IPOs have a negative price impact on rival firms.

$\mathrm{H}_{2}$ : IPOs have a negative stock price impact on publicly traded firms in the same industry. 
Spillover theories claim that once a company goes public, rival companies would also go public soon. The pioneer company provides information about the company and the sectors to the market, as a result there is a positive externality for going public. Firms in the same sector go public in clusters to take advantage of this positive externality (Alti, 2005; Subrahmanyam and Titman, 1999). IPO volume and average initial returns are highly auto-correlated (Lowry and Schwert, 2002).

Clustering of IPOs may also be explained based on market timing theory. Firms in the same sector or same industry are overvalued at about the same time by the market. Many firms are overvalued simultaneously in the clustering periods. Once a pioneer company in an overvalued sector goes public, peers from the same sector or from other overvalued sectors follow the pioneer company. Companies want to take advantage of market conditions (Loughran, Ritter and Rydqvist, 1994; Plotnicki and Szyszka, 2014; Rajan and Servaes, 1997). As a result, we can expect that more companies go public in hot issue periods. Having a negative price impact on publicly traded rival companies, IPOs would result a stronger effect in hot issue periods.

$H_{3}:$ The negative stock price effect on publicly traded companies in the same sector is stronger in hot markets.

\section{Methodology and Data}

\subsection{Methodology}

This study uses industry comparable valuation method to measure valuation effects of IPOs. It follows Purnanadam and Swaminathan (2003) with some adjustments to their ratios. The original paper compares IPO P/V ratios with a peer company in the same sector. This paper uses industry average values to compare the valuation effects of IPO firms. For each firm, three price-to-value $(\mathrm{P} / \mathrm{V})$ ratios are computed. Price is the offer price multiplied by the number of shares outstanding and value is the intrinsic value computed from market average comparable values based on sales, EBITDA, and earnings. The P/V ratio is computed by dividing the IPO offer price multiple by the market average market multiple. The V/P ratios are computed as below:

$$
\begin{gathered}
\left(\frac{\mathrm{P}}{\mathrm{S}}\right)_{\mathrm{IPO}}=\frac{\text { Offer price } * \text { Number of shares outstanding }}{\text { Prior fiscal year sales }} \\
\left(\frac{\mathrm{P}}{\text { EBITDA }}\right)_{\text {IPO }}=\frac{\text { Offer price } * \text { Number of shares outstanding }}{\text { Prior fiscal year EBITDA }} \\
\left(\frac{\mathrm{P}}{\mathrm{E}}\right)_{\text {IPO }}=\frac{\text { Offer price } * \text { Number of shares outstanding }}{\text { Prior fiscal year earnings }}
\end{gathered}
$$

Earnings are annual net income and the number of shares outstanding are number of shares outstanding at the close on the offer date. Price multiples of market values are computed as follows:

$$
\left(\frac{\mathrm{P}}{\mathrm{S}}\right)_{\text {Sector }}=\frac{\text { MarCap of the sector }}{\text { Prior fiscal year total sales of public firms in the sector }}
$$




$$
\left(\frac{\mathrm{P}}{\text { EBITDA }}\right)_{\text {Sector }}=\frac{\text { MarCap of the sector }}{\text { Prior fiscal year total EBITDA of public firms in the sector }}
$$

$$
\left(\frac{\mathrm{P}}{\mathrm{E}}\right)_{\text {Sector }}=\frac{\text { MarCap of the sector }}{\text { Prior fiscal year total earnings of public firms in the sector }}
$$

MarCap of the sector is the total size of the firms in the industry. It is computed as an equal weighted average of size (price multiplied by the number of shares outstanding) for each company in that sector. The P/V ratios of the IPO firm based on price multiples are computed as follows:

$$
\begin{aligned}
& \left(\frac{\mathrm{P}}{\mathrm{V}}\right)_{\text {Sales }}=\frac{(\mathrm{P} / \mathrm{S})_{\text {IPO }}}{(\mathrm{P} / \mathrm{S})_{\text {Sector }}} \\
& \left(\frac{\mathrm{P}}{\mathrm{V}}\right)_{\text {EBITDA }}=\frac{(\mathrm{P} / \text { EBITDA })_{\text {IPO }}}{(\mathrm{P} / \mathrm{EBITDA})_{\text {Sector }}} \\
& \left(\frac{\mathrm{P}}{\mathrm{V}}\right)_{\text {Earnings }}=\frac{(\mathrm{P} / \mathrm{E})_{\mathrm{IPO}}}{(\mathrm{P} / \mathrm{E})_{\text {Sector }}}
\end{aligned}
$$

The initial returns are computed as a percentage price change between the first trading day price and the offer price by equation (10). $\mathrm{P}_{\mathrm{i}, 1}$ represents first trading day closing price and $\mathrm{P}_{\mathrm{i}, \mathrm{o}}$ represents the offer price of the IPO.

$$
\mathrm{R}_{\mathrm{i}, 1}=\left[\frac{\mathrm{P}_{\mathrm{i}, 1}-\mathrm{P}_{\mathrm{i}, \mathrm{o}}}{\mathrm{P}_{\mathrm{i}, \mathrm{o}}}\right] * 100
$$

Market-adjusted returns are computed to measure abnormal returns for each stock.

$$
\mathrm{AR}_{\mathrm{i}, 1}=\mathrm{R}_{\mathrm{i}, 1}-\mathrm{R}_{\mathrm{m}, 1}
$$

where $A R_{i, 1}$ is the daily abnormal return of stock $i$ at day $1 . R_{i}$ is the daily return of stock $i$ and $\mathrm{R}_{\mathrm{m}}$ is the daily stock market portfolio return. BIST100 index is assumed to be the average return on the market portfolio.

An alternative measure of stock market portfolio return is the sector-adjusted abnormal return. Sector-adjusted abnormal returns are used to evaluate rival firms' price changes on event days, or IPO offer dates.

$$
\mathrm{AR} \_\mathrm{Sec}_{\mathrm{i}, 1}=\mathrm{R}_{\mathrm{i}, 1}-\mathrm{R}_{\mathrm{s}, 1}
$$

where $R_{s}$ is the series of sectoral index returns. $R_{s}$ is formed only for IPO offer dates. Each company's sector is determined, and sectoral index return is computed for the offer day. For example, if the company is operating in the technology sector, then the new series uses daily returns of BIST Technology Index (XBLSM). The indexes representing each sector are displayed in Table A-1. Sectoral index returns on IPO days are merged to form a series. Thus, $\mathrm{R}_{\mathrm{s}}$ series has a combination of several sector indexes for 124 days. Missing index values are replaced with BIST100 index.

Mean values are presented but median values are used to test the statistical significance because the data are not normally distributed. Wilcoxon sign-rank test is employed to test the statistical significance of median values. 


\subsection{Sample Construction}

Data span of the analysis is 9 years from January 2010 to December $2018^{1}$. One reason to limit the time frame is that it is easier to find sales, EBITDA, and earnings values of companies for the last 10 years. Data for IPOs are collected from BIST datastore and Capital Markets Board of Turkey website and combined. This dataset provides a list of IPOs, dates, sales type, intermediary names, offer prices, number of investors and related information. The data set has 124 IPOs to analyze for the entire sample period. Sector to which firms belong and list of rival companies are obtained from the sector lists in Public Disclosure Platform website. Daily share prices, number of shares outstanding, sales, EBITDA, earning values, daily prices and volumes of indexes are obtained from EquityRT.

Table 1. Summary of P/V Ratios

\begin{tabular}{lllccc}
\hline Variables & $\mathbf{N}$ & Mean & Median & Minimum & Maximum \\
\hline $\boldsymbol{P} / \boldsymbol{V}_{\text {Sales }}$ & 76 & 4.69 & 0.21 & 0.00 & 200.09 \\
$\boldsymbol{P} / \boldsymbol{V}_{\boldsymbol{E} \text { eITDA }}$ & 77 & 0.18 & 0.05 & -37.45 & 15.75 \\
$\boldsymbol{P} / \boldsymbol{V}_{\text {Earnings }}$ & 79 & 1.17 & 0.01 & -48.83 & 51.78 \\
\hline Note: This table provides the summary of $P / V_{\text {Sales }}, P / V_{E B I T D A}, P / V_{\text {Earnings }}$ ratios. $P / V_{\text {Sales }}$ is \\
the price-to-value ratio computed based on prior year's sales. $P / V_{E B I T D A}$ is the price-to- \\
value ratio computed based on prior year's EBITDA. $P / V_{\text {Earnings }}$ is the price-to-value \\
ratio computed based on prior year's net earnings.
\end{tabular}

A summary of $\mathrm{P} / \mathrm{V}$ ratios are presented in Table 1 . Number of $P / V_{\text {Sales }}$ is 76 . There is a large gap between the mean and the median: the mean value is 4.69 and the median values is 0.21 , indicating right skew. Number of observations for $P / V_{E B I T D A}$ is 77 . The gap between the mean and the median is much smaller, indicating a symmetric distribution of values in the sample. The minimum value is -37.45 , indicating negative EBITDA values in some samples. There are $79 P / V_{\text {Earnings }}$ observations in the sample. The difference between the mean and median is smaller than the one for $P / V_{\text {Sales. }}$ Similar to EBITDA values, net earnings have some negative values. The difference among the number of observations for the three ratios is due to data availability.

A summary of IPO volume, initial market-adjusted abnormal returns, and sector-adjusted abnormal returns per year are presented in Table 2. Number of IPOs $(N)$ is the number of IPOs realized a year. Initial abnormal return $(A R)$ is the abnormal return calculated as difference between daily company return and daily stock market index return. Sectoral abnormal return $\left(A R \_S e c\right)$ is the abnormal return calculated as difference of daily company return and daily sectoral return index return.

Table 2 indicates that the mean and median values of both sector-adjusted initial returns are slightly higher than those of market-adjusted initial returns. The slightly higher sectoradjusted initial abnormal returns imply that sectoral index returns are lower than the market index returns. This can be a result of intra-industry effects of IPOs. Sector indexes are, on average, lower than the market index on IPO days. However, the difference is small: $0.08 \%$ for overall average values, and $0.04 \%$ for overall median values. Moreover, average AR in column four are the annual initial underpricing values of IPOs. Abnormal returns are always positive

\footnotetext{
${ }^{1}$ Ethics of research and publication were followed in this study, which does not require permission from the ethics committee and/or legal/special permission.
} 
except from 2016, which means that there is almost always underpricing in Turkish IPOs on average. The average level of underpricing is $4.88 \%$ for the entire sample period.

Table 2. Times Series Summary of IPOs and Initial Abnormal Returns

\begin{tabular}{cccccc}
\hline Year & $\boldsymbol{N}$ & Average $\boldsymbol{A R} \_$Sec & Median $\boldsymbol{A R} \_$Sec & Average $\boldsymbol{A R}$ & Median $\boldsymbol{A R}$ \\
\hline 2010 & 20 & $5.20 \%$ & $3.64 \%$ & $5.10 \%$ & $3.87 \%$ \\
2011 & 27 & $5.98 \%$ & $4.87 \%$ & $5.97 \%$ & $5.19 \%$ \\
2012 & 26 & $4.08 \%$ & $0.24 \%$ & $4.07 \%$ & $-0.25 \%$ \\
2013 & 18 & $6.40 \%$ & $1.36 \%$ & $6.47 \%$ & $1.74 \%$ \\
2014 & 13 & $3.17 \%$ & $1.85 \%$ & $2.90 \%$ & $0.79 \%$ \\
2015 & 6 & $4.86 \%$ & $3.41 \%$ & $4.34 \%$ & $3.12 \%$ \\
2016 & 2 & $-1.32 \%$ & $-1.32 \%$ & $-0.83 \%$ & $-0.83 \%$ \\
2017 & 3 & $3.71 \%$ & $3.31 \%$ & $4.04 \%$ & $4.39 \%$ \\
2018 & 9 & $5.53 \%$ & $1.76 \%$ & $5.12 \%$ & $1.55 \%$ \\
Total & 124 & $4.96 \%$ & $1.78 \%$ & $4.88 \%$ & $1.74 \%$ \\
\hline
\end{tabular}

Note: This table provides annual summary of number of IPOs, average and median sectoradjusted initial abnormal return (AR_Sec), average and median market-adjusted initial abnormal return $(A R)$ for 2010-2018 period.

\section{Empirical Findings}

\subsection{IPO Valuation}

The first section of this study aims to measure IPO firms' valuation by comparing company valuations with sector value averages. Table 3 presents the number of observations, the mean, and the 25th, 50th, and 75th percentiles of cross-sectional distributions of P/V ratios based on P/S, P/EBITDA, and P/E multiples. Each line provides summary of annual P/V ratios. The last column of the table presents the Z-value from Wilcoxon rank sum test with the null hypothesis that the median $\mathrm{P} / \mathrm{V}$ value is equal to 1 . This test is run only once for the entre sample for each ratio because number of annual IPOs is not sufficient for a statistical test.

The annual median values of $P / V_{\text {Sales }}, P / V_{\text {EBITDA, }}$ and $P / V_{\text {Earnings }}$ are less than 1 for 20102015 period. There is no observations for 2016. There are only three observations for 2017 and 2018. The median values of these three observations are greater than one. The overall median $P / V_{\text {Sales }}, P / V_{\text {EBITDA }}, P / V_{\text {Earnings }}$ are $0.21,0.05$, and 0.01 respectively. The Z-values are -1.96, 4.02 , and and -4.97 , respectively, all of which are significant at $5 \%$ level. The mean value of $P / V_{\text {Sales }}$ is 4.69 , significantly different from 0 ; however, the mean values of other variables are not significant. Overall, results show that IPO companies are not overvalued when their sales, EBITDA, and earnings valued are compared to industry averages. 
Table 3. Time Series Summary of P/V Ratios

\begin{tabular}{|c|c|c|c|c|c|c|}
\hline Year & $\mathbf{N}$ & Mean & $25 \%$ & Median & $75 \%$ & Z-Test \\
\hline \multicolumn{7}{|l|}{$P / V_{\text {Sales }}$} \\
\hline 2010 & 14 & 1.37 & 0.05 & 0.15 & 1.04 & \\
\hline 2011 & 18 & 1.86 & 0.00 & 0.62 & 2.85 & \\
\hline 2012 & 17 & 1.79 & 0.01 & 0.28 & 0.93 & \\
\hline 2013 & 14 & 1.74 & 0.02 & 0.14 & 1.65 & \\
\hline 2014 & 7 & 31.46 & 0.03 & 0.21 & 16.27 & \\
\hline 2015 & 3 & 0.10 & 0.00 & 0.11 & 0.18 & \\
\hline 2016 & 0 & . & . & . & . & \\
\hline 2017 & 1 & 25.50 & 25.50 & 25.50 & 25.50 & \\
\hline 2018 & 2 & 1.41 & 1.04 & 1.41 & 1.78 & \\
\hline Overall & 76 & 4.69 & 0.03 & 0.21 & 1.43 & -1.96 \\
\hline \multicolumn{7}{|l|}{$P / V_{\text {EBITDA }}$} \\
\hline 2010 & 17 & 0.19 & 0.00 & 0.06 & 0.14 & \\
\hline 2011 & 20 & -0.95 & 0.00 & 0.16 & 0.72 & \\
\hline 2012 & 16 & 0.28 & 0.00 & 0.01 & 0.23 & \\
\hline 2013 & 14 & 0.27 & 0.00 & 0.04 & 0.10 & \\
\hline 2014 & 3 & 0.24 & 0.01 & 0.09 & 0.62 & \\
\hline 2015 & 4 & 0.05 & 0.01 & 0.02 & 0.09 & \\
\hline 2016 & 0 & . & . & . & . & \\
\hline 2017 & 1 & 5.10 & 5.10 & 5.10 & 5.10 & \\
\hline 2018 & 2 & 7.59 & 3.59 & 7.59 & 11.59 & \\
\hline Overall & 77 & 0.18 & 0.00 & 0.05 & 0.59 & -4.02 \\
\hline \multicolumn{7}{|l|}{$P / V_{\text {Earnings }}$} \\
\hline 2010 & 15 & 0.11 & -0.07 & 0.02 & 0.21 & \\
\hline 2011 & 18 & 0.81 & -0.20 & 0.00 & 0.65 & \\
\hline 2012 & 18 & 0.02 & -0.05 & 0.00 & 0.02 & \\
\hline 2013 & 14 & 4.38 & 0.00 & 0.08 & 0.83 & \\
\hline 2014 & 7 & -1.19 & -0.11 & 0.02 & 1.64 & \\
\hline 2015 & 4 & 0.05 & 0.00 & 0.05 & 0.09 & \\
\hline 2016 & 0 & . & . & . & . & \\
\hline 2017 & 1 & 19.19 & 19.19 & 19.19 & 19.19 & \\
\hline 2018 & 2 & 1.57 & -1.06 & 1.57 & 4.20 & \\
\hline Overall & 79 & 1.17 & -0.01 & 0.01 & 0.26 & -4.97 \\
\hline
\end{tabular}

Note: This table provides the summary of $P / V_{\text {Sales }}, P / V_{E B I T D A}, P / V_{\text {Earnings }}$ ratios per year. $P / V_{\text {Sales }}$ is the price-to-value ratio computed based on prior year's sales. $P / V_{E B I T D A}$ is the price-to-value ratio computed based on prior year's EBITDA. $P / V_{\text {Earnings }}$ is the price-to-value ratio computed based on prior year's net earnings. $N$ is number of IPOs per year. $25 \%$ and $75 \%$ are the $25^{\text {th }}$ and $75^{\text {th }}$ percentiles of the data. Z-test is Wilcoxon rank sum test. *** $\mathrm{p}<0.01, * * \mathrm{p}<0.05, * \mathrm{p}<0.1$.

Figure 1 displays the annual overvaluation of IPOs. The figure illustrates no overvaluation between 2010 and 2015. There is a large overvaluation effect in 2017, which is caused of the IPO of one overvalued company. Overvaluation effects reduce but do not vanish in 2018. The overvaluation in the last two years is an exception and does not affect the overall results significantly. 


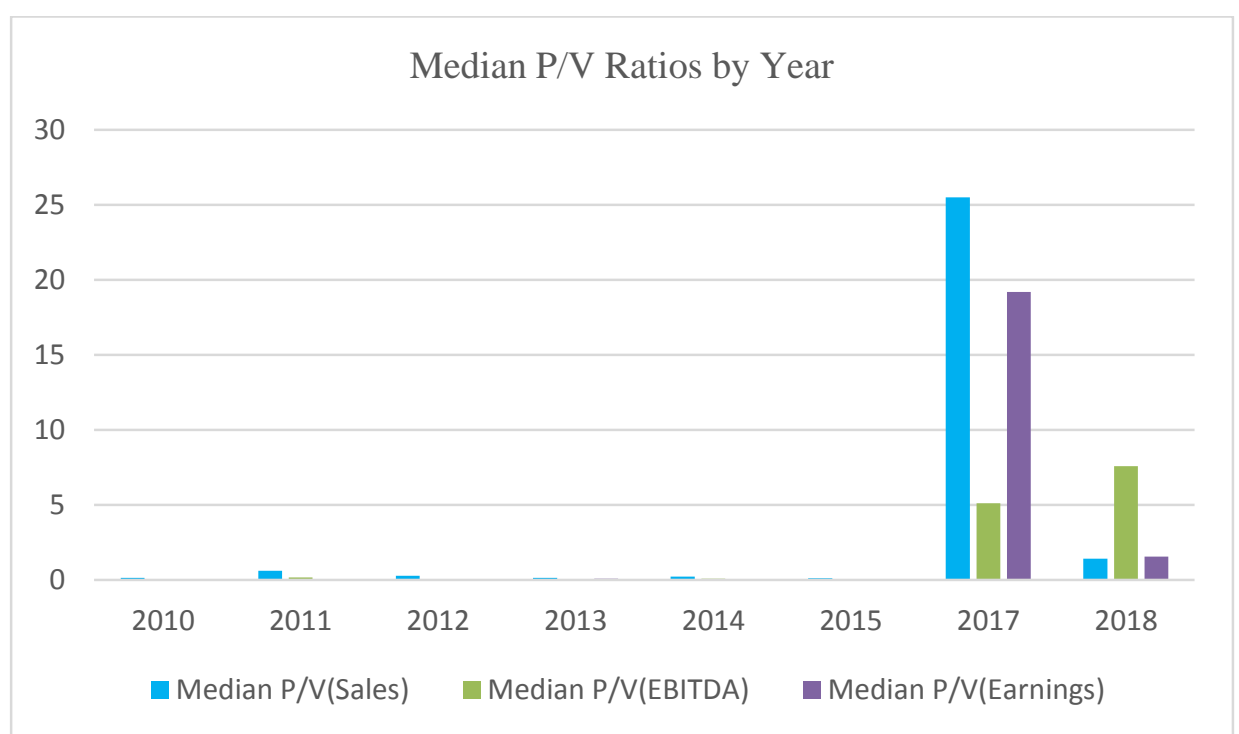

Figure 1. Median P/V Sales, $P / V_{\text {EBITDA, }} P / V_{\text {Earnings }}$ Ratios by Year

Table 4 shows the Spearman correlation matrix between P/V ratios. Correlations between the three $\mathrm{P} / \mathrm{V}$ ratios are positive. The correlation coefficient between $P / V_{\text {Sales }}$ and $P / V_{E B I T D A}$ is $55 \%$, which indicates a strong correlation between these two variables. The correlation coefficients of these two variables with $P / V_{\text {Earnings }}$ are lower, $25 \%$ and $35 \%$, respectively. The correlation coefficients are high and they do not create a difference in results.

Table 4. Spearman Correlation Matrix

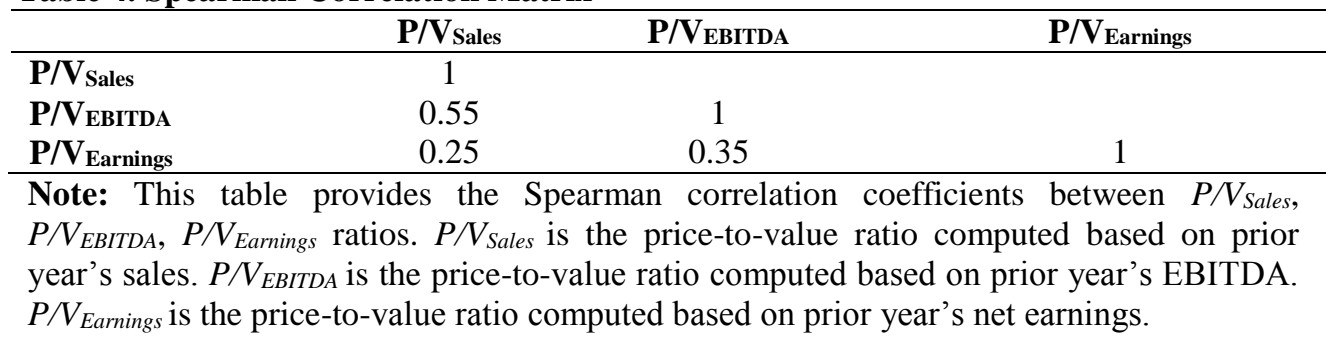

\subsection{IPO Valuation and Initial Underpricing}

This subsection aims to test the relation between initial underpricing and IPO valuations. IPOs have large initial abnormal returns (annual underpricing is displayed in Table 2) and it is possible that initial underpricing is related to IPO valuation. To test the relationship, the following univariate regression is run.

$$
\mathrm{AR}_{\mathrm{i}, \mathrm{t}}=\alpha+\beta \mathrm{P} / \mathrm{V}_{\mathrm{i}, \mathrm{t}}+\varepsilon_{\mathrm{i}, \mathrm{t}}
$$

where $A R$ is the initial abnormal returns, $\mathrm{P} / \mathrm{V}$ is either of $P / V_{\text {Sales }}, P / V_{E B I T D A}$, or $P / V_{\text {Earnings }}$ values. The regression results are displayed in Table 5. 
Table 5. Univariate Regressions Analysis

\begin{tabular}{|c|c|c|c|}
\hline Variables & $\mathbf{A R}$ & $\mathbf{A R}$ & $\mathbf{A R}$ \\
\hline \multirow[t]{2}{*}{$P / V_{\text {Sales }}$} & 0.000 & & \\
\hline & $(0.827)$ & & \\
\hline \multirow[t]{2}{*}{$P / V_{\text {EBITDA }}$} & & 0.001 & \\
\hline & & $(0.637)$ & \\
\hline \multirow[t]{2}{*}{$P / V_{\text {Earnings }}$} & & & -0.001 \\
\hline & & & $(-0.570)$ \\
\hline \multirow[t]{2}{*}{ Constant } & $0.048 *$ & $0.061 * *$ & $0.060 * *$ \\
\hline & $(1.891)$ & $(2.616)$ & $(2.264)$ \\
\hline Observations & 88 & 76 & 77 \\
\hline Time FE & YES & YES & YES \\
\hline R Square & 0.06 & 0.07 & 0.06 \\
\hline \multicolumn{4}{|c|}{$\begin{array}{l}\text { Note: This table provides coefficients from the univariate regression analysis betweer } \\
\text { initial market-adjusted abnormal returns of IPOs }(A R) \text { and } P / V_{\text {Sales }}, P / V_{E B I T D A}, P / V_{\text {Earning }} \\
\text { ratios. } P / V_{\text {Sales }} \text { is the price-to-value ratio computed based on prior year's sales. } P / V_{E B I T D A} \text { i } \\
\text { the price-to-value ratio computed based on prior year's EBITDA. } P / V_{\text {Earnings }} \text { is the price } \\
\text { to-value ratio computed based on prior year's net earnings. OLS regression is used witl } \\
\text { time fixed effects. Robust t-statistics in parentheses. }{ }^{* * *} \mathrm{p}<0.01,{ }^{* *} \mathrm{p}<0.05,{ }^{*} \mathrm{p}<0.1\end{array}$} \\
\hline
\end{tabular}

Table 5 shows the cross-sectional regression coefficients with fixed time effects and robust standard errors. The coefficients are all small, about zero. Clearly, the economic and statistical significance of the relation between $\mathrm{P} / \mathrm{V}$ ratios and $A R$ are very small. The t-statistics of the three variables indicate an insignificant relation between abnormal initial returns and valuation metrics. Overall, we observe that Turkish IPOs are not overvalued between 2010 and 2018, and IPO valuation has no relation with the initial abnormal returns. These results are similar to Indian evidence (Gupta and Suri, 2017).

\subsection{Price Reactions of Rival Firms}

This subsection of this study is to measure intra industry impacts of IPOs. As earlier research suggests rival firms are expected to be undervalued when a firm goes public (Akhigbe et al., 2003; Chemmanur and Fulghieri, 1994; Hsu, Reed and Vocholl, 2010; Nanda, 1991; Slovin et al., 1995; Spiegel and Tookes, 2020; Stoughton, Wong and Zechner, 2001). One indirect way to measure the sectoral undervaluation is to compute abnormal returns as a difference between daily company return and average sectoral return. If abnormal returns computed using sectoral average returns are higher than the abnormal returns computed using market average returns, we can claim that public firms in that sector are subject to negative price effects of IPOs.

Comparing IPO firms with a matched peer would cause several missing IPOs because several firms do not have an appropriate peer in the same industry. Peers matching also ignores other rivals in the industry. As a result, we compute the abnormal returns of all companies in the same sector and take an equal weighted average to compare with the IPO abnormal returns. 
Table 6 provides a summary of sector-adjusted abnormal returns $\left(A r_{-} S e c\right)$ and marketadjusted abnormal returns $(A R)$ for the entire sample (Panel A), industrial firms only (Panel B), and financial firms only (Panel C). Mean $A r \_S e c$ and $A R$ values are all positive and significant. Median values for these values are also positive and significant. The third line in each panel displays the difference between $A R-S e c$ and $A R$ values. The difference is positive and for the entire sample and for the industrial firms, and negative for financial firms. The difference is statistically insignificant for all subsamples. We can interpret the results such that even though sector returns fall slightly more than market returns on IPO days, the difference is not statistically significant.

Table 6. Summary of Initial Abnormal Returns

\begin{tabular}{lccccccc}
\hline \multicolumn{2}{c}{ Observations } & Mean & Median & Minimum & Maximum & T-stat & Z-stat \\
\hline Panel A: Entire Sample & & & & & & \\
\hline AR_sec & 130 & $5.06 \%$ & $1.82 \%$ & $-17.50 \%$ & $31.98 \%$ & 6.34 & 5.11 \\
AR & 130 & $4.97 \%$ & $1.78 \%$ & $-17.49 \%$ & $31.55 \%$ & 6.23 & 4.88 \\
Difference & & $0.08 \%$ & & & & 0.87 & 0.98 \\
\hline Panel B: Industrial Firms & & & & & & \\
\hline AR_sec & 99 & $5.10 \%$ & $2.60 \%$ & $-17.50 \%$ & $31.98 \%$ & 5.48 & 4.49 \\
AR & 99 & $4.99 \%$ & $1.96 \%$ & $-17.49 \%$ & $31.55 \%$ & 5.38 & 4.29 \\
Difference & $0.11 \%$ & & & & 1.11 & 0.95 \\
\hline Panel C: Financial Firms & & & & & & \\
\hline AR_sec & 31 & $4.91 \%$ & $1.14 \%$ & $-8.45 \%$ & $22.14 \%$ & 3.16 & 2.35 \\
AR & 31 & $4.93 \%$ & $1.54 \%$ & $-8.48 \%$ & $22.54 \%$ & 3.11 & 2.14 \\
Difference & & $-0.01 \%$ & & & & -0.12 & -0.06 \\
\hline
\end{tabular}

Note: This table provides a summary of sector-adjusted initial abnormal return (AR_Sec), average and median market-adjusted initial abnormal return $(A R)$ for 2010-2018 period. Panel A presents the summary of the entire sample. Panel B and Panel C present the summary of $A R \_S e c$ and $A R$ for industrial firms and financial firms, respectively.

To further investigate the results, we examine the intra-industry effects of IPOs in hot, neutral, and cold issue periods. Market timing theory expects to have a distinguishable pattern in the number of IPOs between hot and cold issue periods. One way to distinguish hot and cold issue periods is to determine the number of issuances in each month and group these numbers into three categories based on quartiles (Helwege and Liang, 2004). Following this method, number of IPOs in each of 108 months in the sample period is determined. The highest quartile months are labelled as hot period. The lowest two quartiles are labelled as a cold period because the number of IPOs is only a few in the lowest quartile; the third and fourth quartiles are named as neutral periods. Based on this classification hot, neutral, and cold periods in the dataset have 72,30 , and 28 observations, respectively. These numbers show that there is clustering in some periods and number of issues is higher in hot periods.

Table 7 provides a summary of sector-adjusted abnormal returns and market-adjusted abnormal returns for the entire sample for the hot (Panel A), neutral (Panel B), and cold (Panel C) periods. The difference in mean values of $A R-S e c$ and $A R$ for hot markets is positive, but the difference in median values is negative. Both values are insignificant. The difference in mean and median values of neutral and cold markets are positive but insignificant. Similar to the preceding table, Table 7 suggests no significant price effects of IPOs on rival firms.

The common conclusion from Tables 6 and 7 is that even though sector-adjusted abnormal returns are slightly higher than market-adjusted abnormal returns, the difference is not 
significant for industries or market types. Conclusively, intra-industry effects of IPOs are not strong in the Turkish market between 2010 and 2018.

Table 7. Summary of Initial Abnormal Returns in Hot, Neutral, and Cold Issue Periods

\begin{tabular}{|c|c|c|c|c|c|c|c|}
\hline & $\mathbf{N}$ & Mean & Median & Minimum & Maximum & T-stat & Z-stat \\
\hline \multicolumn{8}{|c|}{ Panel A: Hot markets } \\
\hline$A R \_s e c$ & 72 & $5.50 \%$ & $1.78 \%$ & $-17.50 \%$ & $31.98 \%$ & 4.78 & 3.82 \\
\hline$A R$ & 72 & $5.39 \%$ & $2.28 \%$ & $-17.49 \%$ & $31.55 \%$ & 4.68 & 3.60 \\
\hline Difference & & $0.10 \%$ & $-0.51 \%$ & & & 0.77 & 0.83 \\
\hline \multicolumn{8}{|c|}{ Panel B: Neutral markets } \\
\hline$A R \_s e c$ & 30 & $5.42 \%$ & $2.31 \%$ & $-9.85 \%$ & $22.34 \%$ & 3.20 & 2.46 \\
\hline$A R$ & 30 & $5.38 \%$ & $1.63 \%$ & $-8.18 \%$ & $22.72 \%$ & 3.21 & 2.42 \\
\hline Difference & & $0.05 \%$ & $0.68 \%$ & & & 0.22 & 0.56 \\
\hline \multicolumn{8}{|c|}{ Panel C: Cold markets } \\
\hline$A R \_s e c$ & 28 & $3.53 \%$ & $2.52 \%$ & $-6.94 \%$ & $19.81 \%$ & 2.65 & 2.32 \\
\hline$A R^{-}$ & 28 & $3.47 \%$ & $1.87 \%$ & $-7.54 \%$ & $20.30 \%$ & 2.57 & 2.16 \\
\hline Difference & & $0.06 \%$ & $0.65 \%$ & & & 0.45 & -0.18 \\
\hline
\end{tabular}

Note: This table provides a summary of sector-adjusted initial abnormal return (AR_Sec), average and median market-adjusted initial abnormal return $(A R)$ for 2010-2018 period. Panel A presents the summary of $A R \_S e c$ and $A R$ for hot issue periods. Panel B and Panel C present the summary of $A R \_S e c$ and $A R$ for neutral and cold issue periods, respectively. Hot issue periods are determined as the top quartile, cold periods are determined as the bottom two quartiles of the series of number of IPOs per each month. The middle (third and fourth) quartiles are the neutral issue periods.

\section{Conclusion}

This paper tests two hypotheses: sectoral IPO valuation using price multiples and intraindustry effects of IPOs in Turkish Stock Exchange. An important feature of this paper is that it brings an innovation to the existing literature by benchmarking IPOs with sector averages rather than industry peers. Ignored in the academic literature, this benchmarking method is widely used in emerging country IPO evaluations (Firth et al., 2008; How et al., 2007; Tütüncü, 2020).

In the first part of the analysis, industry-based valuation effects are analyzed. Price-tovalue ratios based on sales, EBITDA ratio, and earnings of IPO firms are compared with those ratios of industry averages. Results indicate that IPO firms are not overvalued based on these three criteria. The median values of $\mathrm{P} / \mathrm{V}$ ratios are significantly less than one. Even though median sales values of issuing firms are higher than industry averages, EBITDA and earnings values are about industry averages. A possible explanation for this phenomenon comes from Teoh et al. (1998): IPO firms can artificially inflate their sales values in the preceding year of the IPO. We then regress P/V ratios on initial abnormal returns of IPOs. The results show that $\mathrm{P} / \mathrm{V}$ ratios are not related to initial abnormal returns.

The second part of this analysis measures intra-industry effects of IPOs. Sector-adjusted abnormal initial returns and market-adjusted abnormal initial returns are compared to determine if rival companies in the same sector are underpriced more. The tests show that sector-adjusted initial abnormal returns are higher than market-adjusted initial abnormal returns; however, the difference is not statistically significant. As a result, we cannot accept that IPOs trigger a reduction in rival companies' stock prices in the Turkish market.

These two findings suggest a clear view about Turkish IPO market. IPO companies are fairly priced, there is no mispricing at least when it is measured against industry averages. This 
fair pricing has no effect on initial abnormal returns. Companies do not time the market when considering an IPO. Moreover, entrance of a firm in the Stock Exchange does not affect the prices of industry rivals. This can be a result of market efficiency or it can also be a signal of lack of competitiveness within industries. Further research can focus on these issues.

Our results can be used by investors, prospective IPO issuers, financial market regulators and policy makers. First, issuing firms are not overvalued against industry rivals. This indicates that firms, on average, issuing firms are fairly priced. Valuation is not a factor related to initial abnormal returns. Second, IPOs do not impose negative price impact on rival companies in Turkish IPO market. This finding suggests a less competitive IPO market. Market regulators and policy makers can promote IPOs depending on sectoral upswings and downswings so that promotions would be successful.

This study has various limitations such as the availability of data, limited number of observations in the Turkish IPO market, and the lack of industry peers. The results of the first section should be interpreted with caution because the findings are based on the condition that all industry fundamentals are mean-reverting (Gebhardt et al., 2001; King, 1966; Ohlson and Juettner-Nauroth, 2005; Schmalensee, 1985).

Our analysis does not allow us to distinguish the effects of leverage or amortization on company valuation. The effect of depreciation and leverage on overvaluation of IPOs is an avenue for future research. Future research can also search the effect of industrial market-tobook values on IPO valuation or IPO underpricing.

\section{Researchers' Contribution Statement}

The single author is the sole contributor of the article.

\section{Conflict of Interest Statement}

There is no potential conflict of interest in this study. 


\section{References}

Akhigbe, A., Borde, S. F. and Whyte, A. M. (2003). Does an industry effect exist for initial public offerings? Financial Review, 38(4), 531-551. https://doi.org/10.1111/1540-6288.00059

Akhigbe, A., Johnston, J. and Madura, J. (2006). Long-term industry performance following IPOs. The Quarterly Review of Economics and Finance, 46(4), 638-651. https://doi.org/10.1016/j.qref.2005.01.004

Akhigbe, A., Madura, J. and Whyte, A. M. (1997). Intra-industry effects of bond rating adjustments. Journal of Financial Research, 20(4), 545. doi:10.1111/j.1475-6803.1997.tb00265.x

Alford, A. W. (1992). The effect of the set of comparable firms on the accuracy of the price-earnings valuation method. Journal of Accounting Research, 30(1), 94-108. doi:10.2307/2491093

Alti, A. (2005). IPO market timing. The Review of Financial Studies, 18(3), 1105-1138. doi:10.1093/rfs/hhi022

Baker, M. and Wurgler, J. (2002). Market timing and capital structure. The Journal of Finance, 57(1), 132. doi:10.1111/1540-6261.00414

Benveniste, L. M., Ljungqvist, A., Wilhelm Jr., W. J. and Yu, X. (2003). Evidence of information spillovers in the production of investment banking services. The Journal of Finance, 58(2), 577608. doi:10.1111/1540-6261.00538

Bhojraj, S. and Lee, C. M. C. (2002). Who is my peer? A valuation-based approach to the selection of comparable firms. Journal of Accounting Research, 40(2), 407-439. https://doi.org/10.1111/1475679X.00054

Cassia, L., Paleari, S. and Vismara, S. (2004). The valuation of firms listed on the Nuovo Mercato: The peer comparables approach. In G. Giudici and P. Roosenboom (Eds.), The rise and fall of Europe's new stock markets (pp. 113-129). Bingley: Emerald Group Publishing Limited.

Chahine, S. (2004). Long-run abnormal return after IPOs and optimistic analysts' forecasts. International Review of Financial Analysis, 13(1), 83-103. https://doi.org/10.1016/j.irfa.2004.01.004

Chang, K. P. and Tang, Y. M. (2007). Pricing Taiwan's initial public offerings. Asia-Pacific Journal of Accounting and Economics, 14(1), 69-84. doi:10.1080/16081625.2007.9720788

Chemmanur, T. J. and Fulghieri, P. (1994). Investment bank reputation, information production, and financial intermediation. The Journal of Finance, 49(1), 57-79. doi:10.2307/2329135

Cheng, L. T. W. and McDonald, J. E. (1996). Industry structure and ripple effects of bankruptcy announcements. The Financial Review, 31(4), 783-807. https://doi.org/10.1111/j.15406288.1996.tb00897.x

Chevalier, J. A. (1995). Capital structure and product-market competition: Empirical evidence from the supermarket industry. The American Economic Review, 85(3), 415-435. Retrieved from http://www.jstor.org/

Colaco, H. M. J., De Cesari, A. and Hegde, S. P. (2017). Retail investor attention and IPO valuation. European Financial Management, 23(4), 691-727. https://doi.org/10.1111/eufm.12113

Cotter, J., Goyen, M. and Hegarty, S. (2005). Offer pricing of Australian industrial initial public offers. Accounting and Finance, 45(1), 95-125. doi:10.1111/j.1467-629x.2004.00137.x

Crosby, N. (2000). Valuation accuracy, variation and bias in the context of standards and expectations. Journal of Property Investment and Finance, 18(2), 130-161. doi:10.1108/14635780010324240

Deloof, M., De Maeseneire, W. and Inghelbrecht, K. (2009). How do investment banks value initial public offerings (IPOs)? Journal of Business Finance and Accounting, 36(1-2), 130-160. https://doi.org/10.1111/j.1468-5957.2008.02117.x

Duman Atan, S., Özdemir, Z. A. and Atan, M. (2009). Hisse senedi piyasasında zayıf formda etkinlik: İMKB üzerine ampirik bir çalışma. Dokuz Eylül Üniversitesi İktisadi ve İdari Bilimler Fakültesi Dergisi, 24(2), 33-48. Retrieved from https://dergipark.org.tr/en/pub/deuiibfd/ 
Fairfield, P. M., Ramnath, S. and Yohn, T. L. (2009). Do industry-level analyses improve forecasts of financial performance? Journal of Accounting Research, 47(1), 147-178. doi:10.1111/j.1475679X.2008.00313.X

Firth, M., Li, Y. and Wang, S. S. (2008). Valuing IPOs using price-earnings multiples disclosed by IPO firms in an emerging capital market. Review of Pacific Basin Financial Markets and Policies, 11(3), 429-463. doi:10.1142/S0219091508001428

Gebhardt, W. R., Lee, C. M. C. and Swaminathan, B. (2001). Toward an implied cost of capital. Journal of Accounting Research, 39(1), 135-176. doi:10.1111/1475-679x.00007

Geddes, R. (2003). IPOs and equity offerings (Global Capital Markets Series). Oxford: ButterworthHeinemann.

Gupta, C. P. and Suri, S. (2017). Valuation and pricing of Indian IPOs. Vision, 21(4), 375-384. doi:10.1177/0972262917734706

Helwege, J. and Liang, N. (2004). Initial public offerings in hot and cold markets. The Journal of Financial and Quantitative Analysis, 39(3), 541-569. Retrieved from http://www.jstor.org

How, J., Lam, J. and Yeo, J. (2007). The use of the comparable firm approach in valuing Australian IPOs. International Review of Financial Analysis, 16(2), 99-115. https://doi.org/10.1016/j.irfa.2006.09.003

Hsu, H. C., Reed, A. V. and Rocholl, J. (2010). The new game in town: Competitive effects of IPOs. The Journal of Finance, 65(2), 495-528. https://doi.org/10.1111/j.1540-6261.2009.01542

Jain, B. A. and Kini, O. (1994). The post-issue operating performance of IPO firms. The Journal of Finance, 49(5), 1699-1726. doi:10.2307/2329268

Kim, M. and Ritter, J. R. (1999). Valuing IPOs. Journal of Financial Economics, 53(3), 409-437. https://doi.org/10.1016/S0304-405X(99)00027-6

King, B. F. (1966). Market and industry factors in stock price behavior. Journal of Business, 39(1), 139. doi:10.1086/294847

Lev, B. (1969). Industry averages as targets for financial ratios. Journal of Accounting Research, 7(2), 290-299. doi: $10.2307 / 2489971$

LeClair, M. S. (1990). Valuing the closely-held corporation: The validity and performance of established valuation procedures. Accounting Horizons, 4(3), 31. https://doi.org/10.1023/A:1012050524545

Lie, E. and Lie, H. J. (2002). Multiples used to estimate corporate value. Financial Analysts Journal, 58(2), 44-54. https://doi.org/10.2469/faj.v58.n2.2522

Loughran, T., Ritter, J. R. and Rydqvist, K. (1994). Initial public offerings: International insights. PacificBasin Finance Journal, 3(1), 139-140. https://doi.org/10.1016/0927-538X(95)99082-D

Lowry, M. and Schwert, G. W. (2002). IPO market cycles: Bubbles or sequential learning? The Journal of Finance, 57(3), 1171-1200. https://doi.org/10.1111/1540-6261.00458

Lucas, D. J. and McDonald, R. L. (1990). Equity issues and stock price dynamics. The Journal of Finance, 45(4), 1019-1043. doi:10.2307/2328713

Nanda, V. (1991). On the good news in equity carve-outs. The Journal of Finance, 46(5), 1717-1737. doi:10.2307/2328570

Nguyen, T. (2011). Intra-industry effects of IPOs on stock repurchase decisions. SSRN Electronic Journal. doi:10.2139/ssrn.1929203

Ohlson, J. A. and Juettner-Nauroth, B. E. (2005). Expected EPS and EPS growth as determinants of value. Review of Accounting Studies, 10(2-3), 349-365. http://dx.doi.org/10.1007/s11142-005$1535-3$

Ong, C. Z., Mohd-Rashid, R. and Taufil-Mohd, K. N. (2021). IPO valuation using the price-multiple methods: Evidence from Malaysia. Journal of Financial Reporting and Accounting, Advance online publication. doi:10.1108/JFRA-05-2020-0128 
Pagano, M., Panetta, F. and Zingales, L. (1998). Why do companies go public? An empirical analysis. The Journal of Finance, 53(1), 27-64. https://doi.org/10.1111/0022-1082.25448

Paleari, S. and Vismara, S. (2007). Over-optimism when pricing IPOs. Managerial Finance, 33(6), 352367. doi:10.1108/03074350710748722

Parker, D. (1999). A note on valuation accuracy: An Australian case study. Journal of Property Investment and Finance, 17(4), 401-411. doi:10.1108/14635789910282807

Phillips, G. M. (1995). Increased debt and industry product markets an empirical analysis. Journal of Financial Economics, 37(2), 189-238. https://doi.org/10.1016/0304-405X(94)00785-Y

Plotnicki, M. and Szyszka, A. (2014). IPO market timing. The evidence of the disposition effect among corporate managers. Global Finance Journal, 25(1), 48-55. https://doi.org/10.1016/j.gfj.2014.03.005

Purnanandam, A. K. and Swaminathan, B. (2004). Are IPOs really underpriced? The Review of Financial Studies, 17(3), 811-848. https://doi.org/10.1093/rfs/hhg055

Rajan, R. and Servaes, H. (1997). Analyst following of initial public offerings. The Journal of Finance, 52(2), 507-529. doi:10.2307/2329488

Roosenboom, P. (2012). Valuing and pricing IPOs. Journal of Banking and Finance, 36(6), 1653-1664. https://doi.org/10.1016/j.jbankfin.2012.01.009

Ross, S. A. (1977). The determination of financial structure: The incentive-signalling approach. The Bell Journal of Economics, 8(1), 23-40. doi:10.2307/3003485

Sahoo, S. and Rajib, P. (2013). Comparable firm's P/E multiple and IPO valuation an empirical investigation for Indian IPOs. Decision, 40(1/2), 27-46. https://doi.org/10.1007/s40622-013-0008$\mathrm{y}$

Schmalensee, R. (1985). Do markets differ much? American Economic Review, 75(3), 341-351. Retrieved from http://www.jstor.org

Schultz, P. (2003). Pseudo market timing and the long-run underperformance of IPOs. The Journal of Finance, 58(2), 483-517. https://doi.org/10.1111/1540-6261.00535

Slovin, M. B., Sushka, M. E. and Ferraro, S. R. (1995). A comparison of the information conveyed by equity carve-outs, spin-offs, and asset sell-offs. Journal of Financial Economics, 37(1), 89-104. https://doi.org/10.1016/0304-405X(94)00796-4

Slovin, M. B., Sushka, M. E. and Polonchek, J. A. (1992). Informational externalities of seasoned equity issues: Differences between banks and industrial firms. Journal of Financial Economics, 32(1), 87-101. https://doi.org/10.1016/0304-405X(92)90026-T

Spiegel, M. and Tookes, H. (2020). Why does an IPO affect rival firms? Review of Financial Studies 33(7), 3205-3249. doi:10.1093/rfs/hhz081

Stoughton, N. M., Wong, K. P. and Zechner, J. (2001). IPOs and product quality. The Journal of Business, 74(3), 375-408. doi:10.1086/321931

Subrahmanyam, A. and Titman, S. (1999). The going-public decision and the development of financial markets. The Journal of Finance, 54(3), 1045-1082. https://doi.org/10.1111/0022-1082.00136

Szewczyk, S. H. (1992). The intra-industry transfer of information inferred from announcements of corporate security offerings. The Journal of Finance, 47(5), 1935-1945. doi:10.2307/2329002

Teoh, S. H., Welch, I. and Wong, T. J. (1998). Earnings management and the underperformance of seasoned equity offerings. Journal of Financial Economics, 50(1), 63-99. https://doi.org/10.1016/S0304-405X(98)00032-4

Turan Kurtaran, A., Kurtaran, A. and Kurtaran Çelik, M. (2018). Zayıf formda piyasa etkinliğinin Türkiye hisse senedi piyasasında test edilmesi [Prof. Dr. Harun Terzi özel sayısı]. Uluslararası Íktisadi ve İdari Incelemeler Dergisi, 457-474. https://doi.org/10.18092/ulikidince.456639 
S. Burcu Avc1, "IPO Valuation and IPO Inter-Industry Effects"

Tütüncü, L. (2020). Valuation and underpricing of Turkish IPOs. Journal of Business Economics and Management, 21(1), 157-179. https://doi.org/10.3846/jbem.2020.11927

Welch, I. (1989). Seasoned offerings, imitation costs, and the underpricing of initial public offerings. The Journal of Finance, 44(2), 421-449. doi:10.2307/2328597

Yücel, Ö. (2016). Finansal piyasa etkinliği: Borsa Istanbul üzerine bir uygulama. International Review of Economics and Management, 4(3), 107-123. doi:10.18825/irem.16916 
Ekonomi, Politika \& Finans Araştırmaları Dergisi, 2021, 6(2): 418-438

Journal of Research in Economics, Politics \& Finance, 2021, 6(2): 418-438

\section{APPENDIX}

Table A-1. Table of Sector Indexes

\begin{tabular}{ll}
\hline Sector & Index \\
\hline Administrative and support service activities & XUHIZ \\
Basic Metal & XMANA \\
Brokerage houses and venture capital investment trusts & XUMAL \\
Chemicals, petroleum, rubber, and plastic products & XKMYA \\
Construction and public work & XINSA \\
Education, health, sports, and other social services & XUHIZ \\
Electricity, gas, and water & XELKT \\
Fabricated metal products, machinery, electronic equipment, and transportation vehicles & XMESY \\
Financial leasing and factoring companies & XFINK \\
Food, beverage, and tobacco & XGIDA \\
Holdings and investment companies & XHOLD \\
Insurance companies & XSGRT \\
Investment trusts & XYORT \\
Mining and Quarrying & XMADN \\
Non-metallic mineral products & XTAST \\
Other manufacturing industry, forestry and logging, and fishing & XUSIN \\
Paper, paper products, printing, and publishing & XKAGT \\
Professional, scientific, and technical activities & XUHIZ \\
Real estate investment trusts & XGMYO \\
Restaurants and hotels & XTRZM \\
Telecommunication & XILTM \\
Textile, wearing apparel and leather & XTEKS \\
Transportation and storage & XULAS \\
Wholesale and retail trade & XTCRT \\
\hline
\end{tabular}

